\title{
Factors Affecting the Teaching of the Theme on "Physics in Technology" in Senior Secondary Schools in Ondo State, Nigeria
}

\author{
Bada, Abiodun Adekunle*, Loyiso C. Jita \\ Faculty of Education, School of Mathematics Natural Science and Technology Education, University of the Free State (RSA), \\ South Africa
}

Received July 19, 2020; Revised August 17, 2020; Accepted September 29, 2020

\section{Cite This Paper in the following Citation Styles}

(a): [1] Bada, Abiodun Adekunle, Loyiso C. Jita , "Factors Affecting the Teaching of the theme on 'Physics in Technology' in Senior Secondary Schools in Ondo State, Nigeria," Universal Journal of Educational Research, Vol. 8, No. 10, pp. 4980 - 4985, 2020. DOI: 10.13189/ujer.2020.081071.

(b): Bada, Abiodun Adekunle, Loyiso C. Jita (2020). Factors Affecting the Teaching of the theme on "Physics in Technology" in Senior Secondary Schools in Ondo State, Nigeria. Universal Journal of Educational Research, 8(10), 4980 - 4985. DOI: 10.13189/ujer.2020.081071.

Copyright $₫ 2020$ by authors, all rights reserved. Authors agree that this article remains permanently open access under the terms of the Creative Commons Attribution License 4.0 International License

\begin{abstract}
The study investigated the factors affecting the teaching of Physics in Technology, a new theme under the Senior Secondary School Physics Curriculum which took effect in Nigeria after the last curriculum review. The study adopted the survey design, which involved all the Senior Secondary School Physics teachers in Ondo, Nigeria and it addressed three objectives. An instrument titled, Questionnaire on the Factors Affecting the Teaching of Physics in Technology (QFATPT), was used to obtain data for the study. The reliability of QFATPT was achieved using Cronbach Alpha Coefficient and a value of 0.76 was obtained. The data collected were analysed using descriptive statistics. Findings from the study showed that Physics teachers were aware that a new theme exists in the curriculum. Furthermore, assessment bodies such as the West African Examinations Council (WAEC) and National Examinations Council (NECO) do not assess students on the new theme. The study concludes that while many teachers may be aware and perhaps even favorably disposed to the new curriculum theme on Physics in Technology, the challenges of access to resources for teaching and the absence of test items of the theme during national and local assessment militate against effective implementation of the newly added topics to the curriculum in schools. The paper closes with suggestions on the need for government to increase the awareness of Theme IV through workshops/seminars for in-service
\end{abstract}

Physics teachers and also ensure the procurement of relevant materials/equipment to support local improvisation by teachers.

Keywords Physics, Physics in Technology, Senior Secondary Schools

\section{Introduction}

Physics, an integral part of sciences taught at the senior secondary school level of education in Nigeria have brought several feats to the development of many nations. The importance of the knowledge of Physics has affected nations positively in recent times. Several researchers such as Omosewo [1], Erinosho [2], Bada, Akinbobola and Damoroem [3] have highlighted the great importance the subject stands among the sciences. Bada [4] opined that Physics is a fundamental science subject required for the improvement of any country. This is because the subject plays a significant role in the world of science. The current senior secondary school Physics curriculum is designed under six themes namely; Interaction of Matter, Space and Time; Conservation Principles; Waves; fields; Energy Quantization and Duality of Matter; and Physics in Technology. All these themes have several topics clearly 
designed under them, to be taught to students in the senior secondary schools. The study of all this topics will no doubt increase the good performance of students in the subject. Having said these, the performance of students in the subject relies majorly on the proper teaching and assessment of the themes in the Physics curriculum. A careful review of students' performance in the subject reveals that students are yet to record one hundred percent performance in the subject. What is responsible for this relative poor performance may be due to the relative difficulty experienced by students in some, if not all the themes listed in the Physics curriculum. Omosewo [5] and Erinosho [2] believed that Physics students experience a level of difficulty in some topics when compared to others. In the study carried out by Obafemi and Onwioduokit [6] and Bada, Akinbobola and Damoroem [3], several topics were reported to be difficult for Physics students. Some of these concepts include waves, pressure, electricity, magnetism and nuclear Physics. Bada, Akinbobola and Damoroem [3] in their study found out that the highest level of difficulty was experienced by students under Theme VI (Physics in Technology), with an average difficulty percentage of $36.1 \%$, followed by Theme V, Theme IV, Theme III, Theme I and Theme II with average difficulty percentages of $26.5 \%, 17.3 \%, 16.7 \%, 12.0 \%$ and $10.9 \%$ respectively.

Table 1 shows the performance of students in the West African Senior School Certificate Examination (WASSCE) in Chemistry and Physics between 2015 and 2019. Despite the relatively good performance of students in Physics, the best performance of $78.49 \%$ recorded in the year 2018 cannot be compared to the best performance recorded in Chemistry (84.83\%) in the year 2017. The explanation to this trend may not be far-fetched from the inability to teach some topics under the senior secondary school Physics curriculum.

The performance of Nigerian senior secondary school students is yet to be hundred percent. This means that some, if not all the themes in the senior secondary school Physics curriculum are relatively considered difficult. Bada, Akinbobola and Damoroem [3] reported a high level of difficulty under Theme VI- Physics in Technology, which was newly introduced into the Physics curriculum during the last curriculum reform on senior secondary school physics curriculum. The theme was included in the curriculum in order to reduce the abstract nature of some topics hence, making teaching and learning more real. Since the performance of Nigerian senior secondary school students in Physics is not yet excellent, there is the need to take a careful look at the themes that make up the senior secondary school Physics curriculum in order to determine how they affect students' performance in the subject. This study therefore investigated the factors affecting the teaching of Physics in Technology (Theme VI).

The literature on Physics in Technology is relatively scare however, and a review of the literature related to this shows that researchers have reviewed the new curriculum. Daramola and Omosewo [7] reported that the new curriculum which was introduced in the year 2011 have its structure changed from conceptual approach to thematic approach. This was informed by the current national and global issues which directed that related items and topics be presented under themes. The Nigerian Educational Research and Development Council (NERDC) [8] opined that, Physics in Technology was introduced into the new curriculum in order to provide opportunity for the construction and operation of workable devices and also get used to some of the products of current technology. Omosewo [9] in her study found out that many teachers could not teach some topics because they were not taught while in the Colleges of Education and the Universities. This might be responsible for the relative difficulty experienced by students under Them VI- Physics in Technology.

Table 1. Performance of Students in West African Examination Council in Chemistry and Physics Between 2015 and 2019

\begin{tabular}{|c|c|c|c|c|c|c|}
\hline & \multicolumn{3}{|c|}{ Chemistry } & \multicolumn{3}{c|}{ Physics } \\
\hline Year & Total Entry & $\begin{array}{c}\text { Credit Passed } \\
\text { (A1-C6) }\end{array}$ & \% Passed & Total Entry & $\begin{array}{c}\text { Credit Passed } \\
\text { (A1-C6) }\end{array}$ & \% Passed \\
\hline 2015 & 680,357 & 412,323 & 60.60 & 684,124 & 410,543 & 60.01 \\
\hline 2016 & 706,873 & 408,122 & 57.74 & 705,125 & 415,655 & 58.95 \\
\hline 2017 & 377,970 & 320,635 & 84.83 & 377,851 & 205,757 & 54.45 \\
\hline 2018 & 728,551 & 424,231 & 58.22 & 728,354 & 571,687 & 78.49 \\
\hline 2019 & 726,132 & 566,156 & 77.96 & 725,853 & 565,746 & 77.94 \\
\hline
\end{tabular}


The senior secondary school Physics curriculum, which was last reviewed by the Nigerian Educational Research and Development Council (NERDC) in the year 2009 have been faced with several challenges. This is not without any success that the similarities and differences between Physics and technology has been laid to rest. Nwoye and Okafor [10] in their study on Nigerian's nascent secondary school Physics curriculum and the implementation problems revealed some government related problems facing the implementation of the new secondary school Physics curriculum. Their study found out among others that government does not provide resources for the implementation of the curriculum and also, governments rarely organize workshop for science teachers. The researchers also found out some problems related to the challenges being faced by teachers in the new Physics curriculum. These include teachers not being knowledgeable of some content in the new Physics curriculum. Bada, Akinbobola and Damoroem [3] in their study found out that Physics in Technology, Theme VI under the new Physics curriculum, is not usually taught by Physics teachers. This finding by this researchers on the inability of teachers to teach some concepts of the new Physics curriculum is in line with that of Omosewo [9] who opined that Physics teachers at the senior secondary schools could not teach some topics because they were not taught while in the Colleges of Education and the Universities.

Stephen [11] described resources as information carriers which are created to ensure the achievement of objectives in a teaching-learning situation. This implies that resources play a critical role in the dissemination of curriculum contents to the learners. No matter how laudable the Physics curriculum might appear, the successful implementation depends majorly on the availability and sufficient resource materials used by the teacher. Empirical studies such as Josiah [12], Ifeakor [13], Okafor [14], Konyango [15], Arokoyo and Aderonmu [16], Macmillan and Celina [17] have shown that students achieve better learning when appropriate resources are used during teaching learning process. In the study conducted by Stephen [11] on the status of material resources available for effective teaching of physics in senior secondary secondary schools in Akwa Ibom State, the researcher found out that the schools do not have resource materials for teaching and learning Physics. Macmillan and Celina [17] in their study worked on the availability of Physics resources in secondary schools in Nigeria and recommended that Physics teachers should utilize the available teaching and learning resources in schools for optimal performance.

\section{Purpose of the Study}

The main purpose of this study is to investigate the factors affecting the teaching of Physics in Technology in senior secondary schools in Ondo, Nigeria. Specifically, the study found out:

1. the level of Physics teacher awareness of Physics in Technology in the curriculum;

2. if resources were available for the teaching of concepts under Physics in Technology; and

3. if curriculum agencies such as the West African Examinations Council (WAEC), National Examinations Council (NECO) and Unified Tertiary Matriculation Board (UTME) assess students on concepts under Physics in Technology

\section{Research Questions}

1. What is the level of Physics teacher awareness of Physics in Technology in the curriculum?

2. Are resources available for the teaching of concepts under Physics in Technology?

3. Do curriculum agencies such as the West African Examinations Council (WAEC), National Examinations Council (NECO) and Unified Tertiary Matriculation Board (UTME) assess students on concepts under Physics in Technology?

\section{Method}

The study adopted the descriptive survey design and it involved all the senior secondary school Physics teachers in Ondo, Nigeria. Only fifty six (56) Physics teachers were randomly selected for the study. A researcher designed questionnaire was used to elicit information for the study. The questionnaire titled, Questionnaire on the Factors Affecting the Teaching of Physics in Technology (QFATPT), comprised of twenty three (23) items which were later reduced to nineteen (19) items based on the advice from experts. QTATPT was used to collect data for the study and it is comprised of two sections. Section A consist of demographic information of the participants while section B consists of fifteen (15) statements with a 4-point Likert Scale (Strongly Disagree, Disagree, Agree, Strongly Agree). The instrument used was given to two professionals in Science Education to ascertain its validity and their advice were duly effected. The reliability of QFATPT was achieved by trial testing it on a sample that was not part of the main study. A reliability coefficient of 0.76 obtained using Cronbach Alfa coefficient confirms that the instrument was reliable enough for use. The administration of the questionnaire lasted for a period of four weeks in order to cover a relatively reasonable sample. The data collected was analyzed using descriptive statistics.

\section{Results and Discussion}

Table 2 shows the demographic information of respondents. The table reveals that $85.7 \%$ of the respondents were male while $14.3 \%$ of the respondents 
were female. Also, $42.8 \%$ of the respondents have between 1 to 5 years teaching experience, $28.6 \%$ have between 6 to 10 years teaching experience while $28.6 \%$ of the respondents have teaching experience of 11 years and above. Table 2 shows that $35.7 \%$ of the respondents teach in public schools while $64.3 \%$ of the respondents teach in private schools.

Research Question 1: What is the level of Physics teacher awareness of Physics in Technology in the curriculum?

Table 3 shows that teachers with a mean of 3.21 agreed that Physics teachers knew that a new theme, Physics in Technology exist in the senior secondary school physics curriculum. Teachers with a mean of 2.43 disagreed that workshops have been organized for Physics teachers on the theme, Physics in Technology. Also, Physics teachers with a mean of 2.86 agreed that Physics teachers stick with the senior secondary school Physics curriculum as authored by the Nigerian Educational Research and Development Council (NERDC) document, published in the year 2009. Teachers with a mean of 2.50 disagreed that they had access to another senior secondary school Physics curriculum different from the NERDC senior secondary school Physics curriculum. Physics teachers with a mean of 2.29 disagreed that Physics teachers teach the aspect of Physics in Technology when teaching their students. This agrees with Omosewo [1] who opined that Physics teachers at the senior secondary schools could not teach some topics because they were not taught while in the Colleges of Education and in the Faculties of Education.

Research Question 2: Are resources available for the teaching of concepts under Physics in Technology?

Table 4 reveals that teachers with a mean of 2.21 disagreed that Physics teaches have access to the required resources for teaching Physics in Technology concepts. This finding is in agreement with Stephen [11] who found out that resource materials are not available for teaching and learning Physics. The teachers with a mean of 1.79 each, disagreed that government through its agencies have procured resources and that the resources are available and functioning for teaching concepts under Physics in Technology. This is in agreement with Nwoye and Okafor [10] who found out that government do not provide resources for teaching the curriculum. With a mean of 2.29, Physics teachers disagreed that they encourage their students in the improvisation of resources relevant to the teaching of concepts under Physics in Technology. The teachers with a mean of 2.43 disagreed that the senior secondary school Physics textbooks available are not structured to treat concepts under Physics in Technology.

Research Question 3: Do curriculum agencies such as the West African Examinations Council (WAEC), National Examinations Council (NECO) and Unified Tertiary Matriculation Board (UTME) assess students on concepts under Physics in Technology?
Table 2. Demographic Characteristic of Participant

\begin{tabular}{|c|c|c|c|}
\hline \multicolumn{2}{|c|}{ Variable } & Frequency & Percentage \\
\hline \multirow{2}{*}{ Sex } & Male & 48 & 85.7 \\
\cline { 2 - 4 } & Female & 8 & 14.3 \\
\hline \multirow{3}{*}{$\begin{array}{c}\text { Year(s) of } \\
\text { Experience }\end{array}$} & $1-5$ Years & 24 & 42.8 \\
\cline { 2 - 4 } & 6-10 Years & 16 & 28.6 \\
\cline { 2 - 4 } & $11-$ Above & 16 & 28.6 \\
\hline \multirow{2}{*}{$\begin{array}{c}\text { Type of } \\
\text { School }\end{array}$} & Public & 20 & 35.7 \\
\cline { 2 - 4 } & Private & 36 & 64.3 \\
\hline
\end{tabular}

Table 3. Level of Physics Teacher Awareness of Physics in Technology in the Curriculum

\begin{tabular}{|l|l|l|l|}
\hline \multicolumn{1}{|c|}{ Statements } & Mean & Std. & Remarks \\
\hline $\begin{array}{l}\text { Physics teacher know that a new } \\
\text { theme titled Physics in Technology } \\
\text { exist in the new senior secondary } \\
\text { school Physics curriculum. }\end{array}$ & 3.21 & 0.699 & Agreed \\
\hline $\begin{array}{l}\text { Workshops have been organized } \\
\text { for Physics teachers on the theme } \\
\text { Physics in Technology. }\end{array}$ & 2.43 & 0.852 & Disagreed \\
\hline $\begin{array}{l}\text { Physics teacher sticks with the } \\
\text { senior secondary school Physics } \\
\text { curriculum as authored by the } \\
\text { Nigerian Educational Research and } \\
\text { Development Council (NERDC) } \\
\text { document of 2009. }\end{array}$ & 2.86 & 0.663 & Agreed \\
\hline $\begin{array}{l}\text { Physics teacher have access to } \\
\text { another senior secondary school } \\
\text { Physics curriculum different from } \\
\text { the NERDC senior secondary } \\
\text { school physics curriculum. }\end{array}$ & 2.50 & 1.019 & Disagreed \\
\hline $\begin{array}{l}\text { Physics teacher teach the aspect of } \\
\text { Physics in Technology when } \\
\text { teaching their students. }\end{array}$ & 2.29 & 0.726 & Disagreed \\
\hline
\end{tabular}

Std.= Standard Deviation, $\mathrm{SD}=$ Strongly Disagree, $\mathrm{D}=$ Disagree, $\mathrm{A}=$ Agree, SA = Strongly Agree

Mean Decision $=1.00-1.75=\mathrm{SD}, 1.76-2.50=\mathrm{D}, 2.51-3.25=\mathrm{A}$, $3.26-4.00=$ SA

Table 4. Resources Available for the Teaching of Concepts under Physics in Technology

\begin{tabular}{|l|l|l|l|}
\hline \multicolumn{1}{|c|}{ Statements } & Mean & Std. & Remarks \\
\hline $\begin{array}{l}\text { Physics teacher have access to the } \\
\text { required resources for teaching } \\
\text { Physics in Technology concepts. }\end{array}$ & 2.21 & 1.051 & Disagreed \\
\hline $\begin{array}{l}\text { Government through its agencies } \\
\text { have procured resources for } \\
\text { teaching concepts under Physics } \\
\text { in Technology. }\end{array}$ & 1.79 & 0.802 & Disagreed \\
\hline $\begin{array}{l}\text { Resources for teaching concepts } \\
\text { under Physics in Technology are } \\
\text { available and functioning. }\end{array}$ & 1.79 & 0.975 & Disagreed \\
\hline $\begin{array}{l}\text { Physics teachers encourage their } \\
\text { students in the improvisation of } \\
\text { resources relevant to the teaching } \\
\text { of concepts under Physics in }\end{array}$ & 2.29 & 0.994 & Disagreed \\
\begin{tabular}{l} 
Technology. \\
\hline $\begin{array}{l}\text { The senior secondary school } \\
\text { Physics textbooks available are } \\
\text { not structured to treat concepts } \\
\text { under Physics in Technology }\end{array}$
\end{tabular} & 2.43 & 0.756 & Disagreed \\
\hline
\end{tabular}

Std. $=$ Standard Deviation, $\mathrm{SD}=$ Strongly Disagree, $\mathrm{D}=$ Disagree, $\mathrm{A}=$ Agree, $\mathrm{SA}=$ Strongly Agree

Mean Decision $=1.00-1.75=\mathrm{SD}, 1.76-2.50=\mathrm{D}, 2.51-3.25=\mathrm{A}$, $3.26-4.00=\mathrm{SA}$ 
Table 5 shows that teachers with a mean of 2.50 disagreed that Physics students are frequently assessed on the concepts under Physics in Technology by curriculum agencies such as WAEC, NECO and UTME. Again, the teachers with a mean of 2.57 disagreed that questions on the concepts of Physics in Technology are relatively difficult for students to attempt. Teachers with a mean of 2.21 disagreed that concepts under Physics in Technology are not relevant to the knowledge required by the students to pass certificate examinations. This finding might just be responsible for the relatively low performance of students in the subject. Physics teachers with a mean of 2.79 disagreed that they do not enjoy the teaching of the concepts under Physics in Technology.

Table 5. Assessment by Curriculum Agencies

\begin{tabular}{|l|l|l|l|}
\hline \multicolumn{1}{|c|}{ Statements } & Mean & Std. & Remarks \\
\hline $\begin{array}{l}\text { Physics students are frequently } \\
\text { assessed on the concepts under } \\
\text { Physics in Technology. }\end{array}$ & 2.21 & 1.051 & Disagreed \\
\hline $\begin{array}{l}\text { Questions on the concept of } \\
\text { Physics in Technology are } \\
\text { relatively difficult for students to } \\
\text { attempt }\end{array}$ & 1.79 & 0.802 & Disagreed \\
\hline $\begin{array}{l}\text { Concepts under Physics in } \\
\text { Technology are not relevant to } \\
\text { the knowledge required by the } \\
\text { students to pass certificate } \\
\text { examinations }\end{array}$ & 1.79 & 0.975 & Disagreed \\
\hline $\begin{array}{l}\text { As a Physics teacher, I do not } \\
\text { enjoy the teaching of the concepts } \\
\text { under Physics in Technology }\end{array}$ & 2.29 & 0.994 & Disagreed \\
\hline $\begin{array}{l}\text { The teaching of the concepts } \\
\text { under Physics in Technology } \\
\text { have further made the teaching of } \\
\text { Physics more practical }\end{array}$ & 2.43 & 0.756 & Disagreed \\
\hline
\end{tabular}

Std.= Standard Deviation, $\mathrm{SD}=$ Strongly Disagree, $\mathrm{D}=$ Disagree, $\mathrm{A}=$ Agree, $\mathrm{SA}=$ Strongly Agree

Mean Decision $=1.00-1.75=$ SD, $1.76-2.50=\mathrm{D}, 2.51-3.25=\mathrm{A}$, $3.26-4.00=\mathrm{SA}$

This is because teachers' attitude plays a significant role in teaching concepts very well. Physics teachers with a mean of 2.57 disagreed that the teaching of concepts under Physics in Technology has further made the teaching of Physics more practical. This finding does not favour one of the objectives for reviewing the senior secondary school Physics curriculum, which suggests that the new curriculum should encourage the practical nature of the subject.

\section{Recommendations}

Based on the findings from this study, the following recommendations were considered appropriate:

1. Despite the relatively good level of awareness of Physics in Technology in the curriculum, more efforts should be geared towards increasing the awareness of the theme among senior secondary school Physics teachers;
2. Government through its agencies should procure resources for teaching concepts under Physics in Technology;

3. Curriculum agencies such as the West African Examinations Council, National Examinations Council and Unified Tertiary Matriculation Examinations should be encouraged to assess students on concepts under Physics in Technology.

\section{REFERENCES}

[1] E. O. Omosewo. Views of physics teachers on the need to train and retrain physics teachers in Nigeria. An International Multi-Disciplinary Journal, Vol. 3, No. 1, 313-324, 2009.

[2] S. Y. Erinosho. How do students perceive the difficulty of physics in secondary schools: An exploratory study in Nigeria. International Journal for Cross-Disciplinary Subjects in Education, Vol. 3, No. 3, 1510-1515, 2013.

[3] A. A. Bada, A. O. Akinbobola, E. O Damoeroem. Measured identification and remediation of students' weakness in Nigerian senor secondary school Physics curriculum. International Journal of Innovation Research and Advanced Studies, Vol. 5, No. 10, 13-19, 2018.

[4] A. A. Bada. Effects of brain-based and experiential teaching strategies on senior school students' performance in Physics in Ondo, Nigeria. Unpublished Ph.D Thesis, Faculty of Education, University of Ilorin, Nigeria, 2018.

[5] E. O. Omosewo. Why dread the science of the state of the universe? The One Hundred and Eighteen (118th) Inaugural Lecture, University of Ilorin, Ilorin, Nigeria. 2012.

[6] D. T. A. Obafemi, F. A. Onwioduokit. Identification of difficult concepts in senior secondary school two (SS2) Physics curriculum in Rivers State, Nigeria. Asian Journal of Education and e-learning, Vol. 1 No. 3, 317-322, 2013.

[7] S. O. Daramola, E. O. Omosewo. An appraisal of the new Nigerian secondary school Physics curriculum. Journal of Education and Practice, Vol. 3, No. 3, 191-195, 2012.

[8] NERDC. The new senior secondary school curriculum structure at a glance, Abuja, Federal Ministry of Education, 2018.

[9] E. O. Omosewo. Inservice programme for senior Physics teachers for improved teaching and assessment of students. Nigerian Journal of Development Issues: Education Socio-political and Economic Development, Vol. 5, No. (1\&2), 200-219, 2001.

[10] A. N. Nwoye, A. E. Okafor. Nigerian's nascent secondary school Physics curriculum and its implementation problems. Scientific Research Journal (SCIRJ), Vol. 7, No. 6, 62-68, 2019.

[11] U. S. Stephen. The status of material resources for effective teaching of Physics in secondary schools in Akwa Ibom State, Nigeria. An International Multidisciplinary Journal, Ehtiopia, Vol. 5, No. 4, 242-249, 2011. 
[12] M. M Josiah. Effects of practical Physics knowledge on student's achievement: A study of Pankshin Local Government Area of Plateau State, Nigeria. World Educators Forum, Vol. 2, No. 1, 210-218, 2004.

[13] A. C. Ifeakor. Enhancing professional STM teacher's role in lifelong education: Strategies and needs for teachers performance. 46th Annual Conference Proceeding of STAN, 29-133, 2005.

[14] P. N. Okafor. Laboratory resources and utilization as correlates of Chemistry students' learning outcomes. The status of resources for effective teaching of Chemistry in Nigerian secondary schools. 47th Annual Conference Proceedings of STAN, 173-177, 2006.
[15] O. B. Konyango, Impact of resources utilization on the performance of Physics in KCSE in public secondary schools in Ugunja/Ugenja district, Kenya. An Unpublished M.Ed (Planning) Thesis, Kenyatta University, Nairobi, (2011).

[16] A. A. Arokoyo, T. S. B. Aderonmu. Quality of science teaching in public secondary schools in River State: The journey so far. British Journal of Education, Society and Behavioural Science, Vol. 4, No. 12, 1737-1749, 2014.

[17] M. J. Macmillan, S. G. Celina. Physics resources availability and utilization in Nigeria secondary schools. International Journal of Entrepreneurial Development, Education and Science Research, Vol. 5, No. 1, 127-135, 2019. 